\title{
Bibliometric analysis of publications on polycystic ovary syndrome and Turkey's scientific contribution
}

\author{
Polikistik over sendromu konulu yayınların ve Türkiye'nin bilimsel katkısının \\ bibliyometrik analizi
}

\author{
Eyüp Yaycı*, Ömer Tolga Güler, Tijen Ataçağ, Ali Çetin \\ Department of Obstetrics and Gynecology (Assist. Prof. E. Yayc1, MD, Assoc Prof. Ö. T. Güler, \\ MD, Assist. Prof. T. Ataçă̆, MD, Prof. A. Çetin, MD), Near East University School of Medicine, \\ Nicosia, TRNC
}

\begin{abstract}
Aim. Bibliometric studies can be used to evaluate the quantitative scientific performance on a specific topic via evaluating the accumulation of scientific data. Interpreting quantitative performance of a country with respect to bibliometric analyses is an important way to assess the quality and quantity of that country's contribution to the dissemination of medical evidences about a topic. In this study, we aimed to make a quantitative analysis of the scientific publications related to "Polycystic Ovary Syndrome" and also to investigate publications originating from Turkish institutions and authors, which are published in Science Citation Index Expanded covered medical journals. Method. We retrospectively searched papers published in the field of polycystic ovary syndrome between 1980 and 2012 by using the Web of Science software. Papers that were published in Science Citation Index Expanded covered journals were taken into account. Results. Web of Science based search on the field of "Polycystic Ovary Syndrome" through the database of Science Citation Index Expanded from 1980 to the date of the study (June 29, 2012), revealed 8891 English scientific documents. Among these, 2836 (31.9\%) were from United States of America, followed by England $(9.75 \%)$, Italy $(8.45 \%)$, Turkey $(5.34 \%)$. The international scientific repertory on polycystic ovary syndrome was relatively poor in the beginning of 1980 s, however; we observed an international acceleration with respect to the publication number after 1990s. Publications from Turkey on the other hand showed up only after 1990s. Turkey's contribution to international repertory of polycystic ovary syndrome research speeded up after 2000s. When the ranking of the authors with respect to the number of publications was evaluated, Azziz R was found to be the first, followed by Legro RS, and Franks S. Yildiz BO, Kelestimur F, and Yarali $\mathrm{H}$ were the first three among Turkish authors. Fertility and Sterility was found to be the most preferred journal publishing papers about polycystic ovary syndrome. Conclusion. International scientific publications on the field of PCOS started to increase notably after 1990s. Turkey has a prominent place with respect to its contribution to the scientific repertory on the field. This contribution has been steadily increasing during the last decade.
\end{abstract}

Keywords: Bibliometric analysis, polycystic ovary syndrome, polycystic ovary, stein-leventhal syndrome, research activities, Turkey

\section{Özet}

Amaç. Bibliyometrik çalışmalar, özgün bir konu ile ilgili birikmiş bilimsel verileri inceleyerek, o konu ile ilgili nitel bilimsel performansı değerlendirmek için gerçekleştirilir. Bir ülkenin belli bir konu hakkındaki nitel performansının bibliyometrik analiz açısından yorumlanması, o ülkenin medikal veri sunumuna katkısının nitel ve nicel olarak değerlendirilmesinde önemli bir yoldur. Bu çalışmada, 'Polikistik Over Sendromu' ile ilgili bilimsel yayınların kantitatif analizini yapmayı, ayrıca Türk kurumları ve yazarları tarafından yayınlanarak Science Citation Index Expanded kapsamındaki tıbbi dergilerde yer almış yayınları araştırmayı amaçladık. Yöntemler. Web of Science yazılımını kullanarak, 1980-2012 yılları arasında polikistik over sendromu alanında yayınlanmış makaleleri retrospektif olarak araştırdık. Bu amaçla Science Citation İndex Expanded kapsamındaki dergilerde yayınlanmış olan makaleler dikkate alındı. Bulgular. 1980' den araştırma tarihine (29 Haziran 2012) kadarki SCI Expanded veri tabanında yapılan Web of Science temelli 
araştırmada, polikistik over sendromu ile ilgili 8891 adet İngilizce bilimsel dokümana ulaşıldı. Bunların arasında 2836 tanesi $(\% 31,9)$ Amerika Birleşik Devletleri'nden idi. Bunu İngiltere $(\% 9,75)$, İtalya $(\% 8,45)$ ve Türkiye $(\% 5,34)$ 'nin takip ettiği saptandı. 1980'lerin başında polikistik over sendromu ile ilgili uluslararası bilimsel repertuar göreceli olarak yetersizdi, ancak, 1990'lardan sonra yayın sayısında uluslararası bir artış olduğu gözlemlendi. Diğer taraftan, Türkiye kökenli yayınlar 1990'lardan sonra görülmeye başlandı. Polikistik over sendromu araştırmalarının uluslararası repertuarına Türkiye'nin katkısı 2000'lerden itibaren artış gösterdi. Yayın sayısı açısından yazarların sıralamasına bakıldığında; R. Azziz birinci olup, RS. Legro ve S. Franks onu takip etti. Türk yazarlar arasında da ilk üç sırada BO. Yıldız, F. Kelestimur ve H. Yaralı'nın yer aldığı saptandı. Polikistik over sendromu ile ilgili makaleleri yayınlayan dergiler arasında en çok tercih edilenin Fertility Sterility olduğu saptandı. Sonuç. Polikistik over sendromu alanındaki uluslararası bilimsel yayınlarda, 1990'lardan itibaren belirgin artış görülmeye başlandı. Türkiye, bu alandaki bilimsel repertuara yaptığı katkı açısından önemli bir yere sahiptir. Bu katkı son 10 yılda düzenli bir şekilde artış göstermektedir.

Anahtar sözcükler: Bibliyometrik analiz, polikistik over sendromu, polikistik over, SteinLeventhal sendromu, araştırma faaliyetleri, Türkiye

Geliş tarihi/Received: August 19, 2013; Kabul tarihi/Accepted: March 05, 2014

\section{*Corresponding author:}

Dr. Eyüp Yaycı, Kadın Hastalıkları ve Doğum Anabilim Dalı, Yakın Doğu Üniversitesi, K. K. T. C-99118 Mersin10 Türkiye. E-mail: eyupyayci@ hotmail.com

\section{Introduction}

Polycystic ovary syndrome (PCOS) is one of the most common female endocrinopathy, affecting about 5 to 10 percent of the female population. 77 years ago, two American gynecologists Irving F. Stein, Sr. and Michael Leo Leventhal first described this syndrome. The syndrome was considered as a problem of anovulation and infertility. They described their treatment of anovulation using wedge resection [1].

PCOS is an etiologically heterogeneous condition that involves overproduction of ovarian androgens and insulin resistance leading to a various spectrum of symptoms, including hirsutism, acne, anovulation, metabolic syndrome and infertility [2, 3]. PCOS is associated with reproductive and metabolic consequences. The review of findings indicate that the long-term reproductive outcomes of women with PCOS are surprisingly similar compared to women with normal ovaries, and that they have an ovarian reserve possibly superior to women with normal ovaries. The typical features of PCOS, specifically the anovulatory cycles tend to normalize over time, but in spite of a decrease over time, free androgen levels remain elevated compared to age-matched control subjects. Overall, the accumulated data from several European cohort studies of older women with a previous diagnosis of PCOS suggest an increased incidence of type 2 diabetes, increased prevalence of several features of the metabolic syndrome, but no increased incidence of mortality from CVD. [4].

Rotterdam criteria were used for the diagnosis of PCOS [5]. The presences of two of three of the following criteria were used for the diagnosis of PCOS: i) oligo and/or anovulation, ii) clinical and/or biochemical signs of hyperandrogenism, and iii) echographic PCO, after the exclusion of other pathologies with a similar clinical presentation.

Bibliometric analysis is a method for evaluating the quantitative parameters of a field in the scientific literature. Besides, some of these parameters and their improvement trend may also give clues about qualitative features. Therefore, in medicine bibliometric studies can be used to evaluate the global scientific performance or a country's contribution to the accumulation of medical evidences on a specific topic [6].

In general, when scientists realize something important, they want to publish it in peer- 
review journals. Several databases are constituted in order to facilitate the accessibility of these journals and publications. The Science Citation Index includes the world's leading scientific and technical journals, and can be used as a tool for bibliographic information retrieval [7]. The Web of Science is comprised of a software application which can be used for bibliometric assessment of scientific publications indexed in the Science Citation Index Expanded via using several parameters and refinements [8].

PCOS is a long-known yet not completely understood clinical entity. That has both reproductive and metabolic consequences. Multidisciplinary researches and discussions are needed to dissect the complete pathogenesis and to search out for optimal management of this syndrome since it has both reproductive and metabolic consequences. Bibliometric analyses on PCOS therefore, can yield important parameters about what we have achieved scientifically since now, globally. In this study, we aimed to make a quantitative analysis of the scientific publications related to PCOS, published in Science Citation Index Expanded covered medical journals during the last three decades. Our main point of interest was to evaluate the amount and trend of this contribution to the literature. Our secondary outcome was to investigate Turkey's contribution to the accumulation of medical evidences on this subject. To our knowledge, this is the first bibliometric study in English literature, investigating the global scientific performance for the generation of scientific repertory on PCOS.

\section{Materials and methods}

We conducted a bibliometric analyses in June 2012 using the Web of Science software to investigate the scientific publications about PCOS. We retrospectively searched papers published in the field of polycystic ovary syndrome between 1980 and June 2012. We evaluated the papers that are published in the journals covered by Science Citation Index Expanded. We used the following search entries in the search field: "polycystic ovary syndrome", "polycystic ovary" and "Stein-Leventhal syndrome". All matched results were first refined in English language. "Analyze" function of the software was then used to investigate the contribution of the countries, distribution of the publications among years, type of the documents, name of the journals, institutions, and the authors. This analysis was also performed for investigating the Turkey's contribution separately. Publications and the cited papers from Turkey were also analyzed with respect to last three decades.

\section{Results}

Web of Science based search using the defined entries through the database of Science Citation Index Expanded from 1980 to the date of the study (June 29, 2012), revealed 8891 English scientific documents. We made our analysis in this group of publications. Among 8891 English publications, 2836 (31.9\%) were from United States of America, followed by England (9.75\%), Italy (8.45\%), Turkey (5.34\%). All others had a contribution smaller than 5\%. Turkey had $475(5.34 \%)$ publications and ranked 4 . Table 1 presents the contribution of first 10 countries to the field of polycystic ovary syndrome.

Table 1. The contribution of first 10 countries to the scientific repertory on the field of polycystic ovary syndrome.

\begin{tabular}{llll}
\hline Rank & Countries & Number of publications & Percentage $(\%)$ of publications \\
\hline $\mathbf{1}$ & USA & 2836 & 31.9 \\
$\mathbf{2}$ & England & 867 & 9.8 \\
$\mathbf{3}$ & Italy & 751 & 8.5 \\
$\mathbf{4}$ & Turkey & 475 & 5.3 \\
$\mathbf{5}$ & Germany & 332 & 3.7 \\
$\mathbf{6}$ & Greece & 310 & 3.5 \\
$\mathbf{7}$ & Canada & 301 & 3.4 \\
$\mathbf{8}$ & France & 301 & 3.4 \\
$\mathbf{9}$ & Spain & 299 & 3.4 \\
$\mathbf{1 0}$ & Australia & 295 & 3.3 \\
\hline
\end{tabular}


Among the Mediterranean countries, there was 2152 papers published constituting for the $24 \%$ of the global publications. Italy, Turkey and Greece were the three leading Mediterranean counties, respectively (Table 2).

Table 2. The first five Mediterranean countries with respect to the number of publications.

\begin{tabular}{llll}
\hline Rank & Countries & Record Count & \% of 8891 \\
\hline $\mathbf{1}$ & Italy & 751 & 8.5 \\
$\mathbf{2}$ & Turkey & 475 & 5.3 \\
$\mathbf{3}$ & Greece & 310 & 3.5 \\
$\mathbf{4}$ & Spain & 299 & 3.4 \\
$\mathbf{5}$ & Israel & 152 & 1.7 \\
\hline
\end{tabular}

The international scientific repertory on polycystic ovary syndrome was relatively poor in the beginning of 1980s. In example there were only six publications concerning polycystic ovary syndrome in the year of 1980. On the other hand, we observed an international acceleration with respect to the publication number after 1990s. Between 1980 and 1989, there were only 278 (3.13\% of the total publications) publications on the field of polycystic ovary syndrome, however that number increased in $90 \mathrm{~s}$ and reached $1408(15.8 \%)$ between 1990 and 1999 Figure 1.
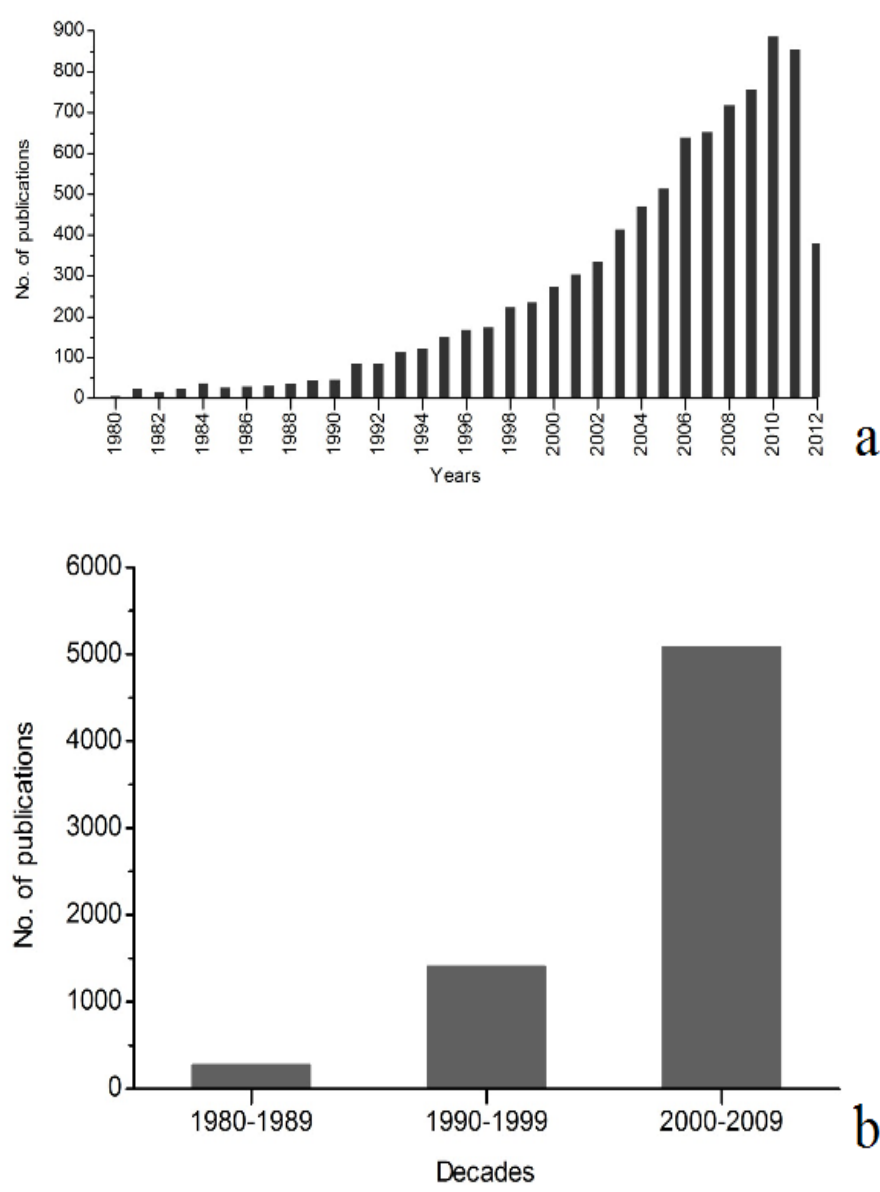

Figure 1. Global trend of publication numbers per years in the field of polycystic ovarian syndrome; a. Global publications with respect to years, b. Global publications with respect to decades.

Publications from Turkey on the other hand showed up only after 1993. Turkey's contribution to international repertory of polycystic ovary syndrome research seems to speed up after 2000. There were $32(6.74 \%)$ and $294(61.89 \%)$ papers published by Turkish authors between 1990-1999 and 2000-2009, respectively. Numbers of publications from Turkey are presented Figure 2. 

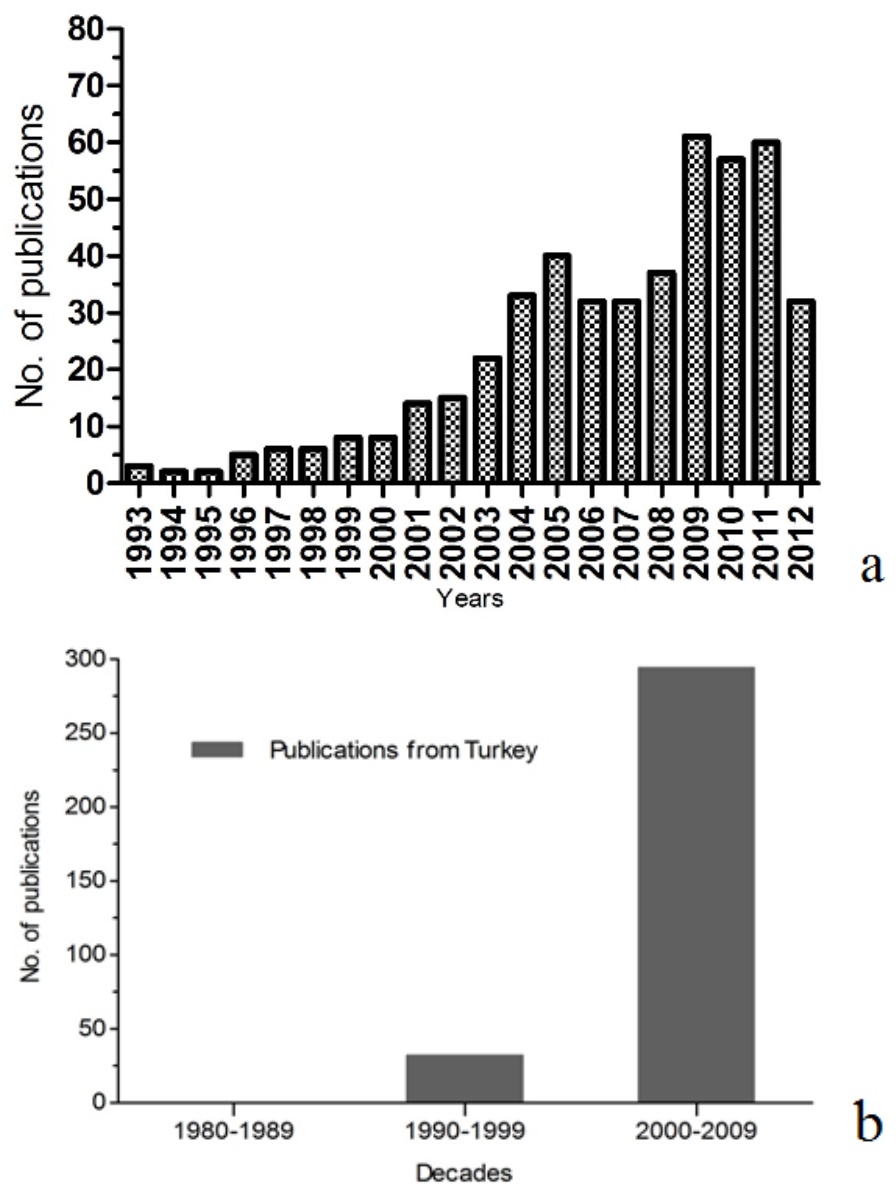

Figure 2. Publications from Turkey per years in the field of polycystic ovarian syndrome; a. Publications from Turkey with respect to years, b. Publications from Turkey with respect to decades.

The document types between 1980 and the date of the study (June 2012), classified by WOS in English SCI-Expanded based literature were as follows: article ( $n=6176$, $69.46 \%)$, review $(n=1149,12.92 \%)$, meeting abstract $(n=895,10.07 \%)$, proceedings paper $(n=513,5.77 \%)$, and others $(n=158,1.78 \%)$. Table 3.

Table 3. Distrubition of the type of the scientific documents in the field of polycystic ovarian syndrome.

\begin{tabular}{lll}
\hline World document type & Number & Percentage (\%) \\
\hline Article & 6176 & 69.5 \\
Review & 1149 & 12.9 \\
Meeting abstract & 895 & 10.1 \\
Proceedings paper & 513 & 5.8 \\
Others & 158 & 1.8 \\
\hline
\end{tabular}

The types of the documents from Turkey were as follows: Article $(n=392,82.53 \%)$, meeting abstract $(n=37,7.79 \%)$, proceedings paper $(n=17,3.58 \%)$, review $(n=13,2.74 \%)$, and others $(n=16,3.37 \%)$.

When the ranking of the authors with respect to the number of publications was evaluated, Azziz R. was found to be the first, followed by Legro RS, and Franks S. The ranking of the first 10 authors worldwide according to the number of their publications is shown in Table 4. 
Table 4. The first 10 authors with respect to the number of publications in the field of polycystic ovarian syndrome.

\begin{tabular}{llll}
\hline & World field; authors & Number of publications & \% of 8891 \\
\hline $\mathbf{1}$ & Azziz R & 184 & 2.1 \\
$\mathbf{2}$ & Legro RS & 156 & 1.8 \\
$\mathbf{3}$ & Franks S & 143 & 1.6 \\
$\mathbf{4}$ & Dunaif A & 121 & 1.4 \\
$\mathbf{5}$ & Norman RJ & 99 & 1.1 \\
$\mathbf{6}$ & Glueck CJ & 93 & 1.0 \\
$\mathbf{7}$ & Lobo RA & 92 & 1.0 \\
$\mathbf{8}$ & Wang P & 91 & 1.0 \\
$\mathbf{9}$ & Fauser BCJM & 90 & 1.0 \\
$\mathbf{1 0}$ & Nestler JE & 87 & 0.9 \\
\hline
\end{tabular}

BO Yildiz (Endocrinologist) $(\mathrm{n}=28,5.89 \%), \mathrm{F}$ Kelestimur (Endocrinologist) ( $\mathrm{n}=24$, $5.05 \%)$, and $\mathrm{H}$ Yarali (Gynecologist) $(\mathrm{n}=20,4.21 \%)$ are the first three among Turkish authors with respect to the number of scientific papers.

Overall, publications from Turkey were cited 4701 times until June 2012. The first citation came from the year of 1994. Number of cited papers from Turkey increased twenty-seven times dramatically between 2000 and 2009. Distribution of the citation number of the publications from Turkey with respect to time is shown in Figure 3.

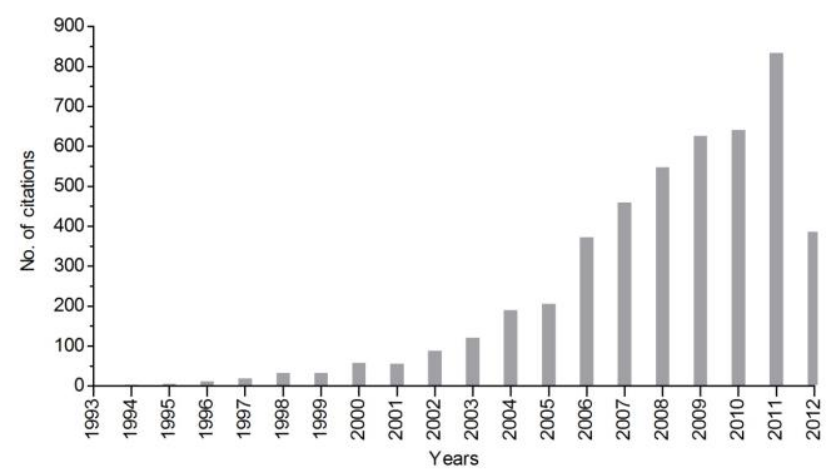

Figure 3. Citation numbers of the publications from Turkey in the field of polycystic ovarian syndrome.

The top 10 journals publishing the papers about PCOS are presented in Table 5.

Table 5. The top 10 journals publishing the papers on the field of polycystic ovarian syndrome.

\begin{tabular}{llll}
\hline & World source titles & Number & \% \\
\hline $\mathbf{1}$ & Fertility and sterility & 1208 & 13.58 \\
$\mathbf{2}$ & Journal of clinical endocrinology metabolism & 676 & 7.60 \\
$\mathbf{3}$ & Human reproduction & 595 & 6.69 \\
$\mathbf{4}$ & Gynecological endocrinology & 328 & 3.68 \\
$\mathbf{5}$ & Clinical endocrinology & 203 & 2.83 \\
$\mathbf{6}$ & European journal of endocrinology & 151 & 1.69 \\
$\mathbf{7}$ & Reproductive biomedicine online & 110 & 1.23 \\
$\mathbf{8}$ & Journal of endocrinological investigation & 106 & 1.19 \\
$\mathbf{9}$ & European journal of obstetrics gynecology and reproductive biology & 101 & 1.13 \\
$\mathbf{1 0}$ & Metabolism clinical and experimental & 90 & 1.01 \\
\hline
\end{tabular}


Between 1980 and June 2012, most of the papers on the field of PCOS was published in Fertility and Sterility $(n=1208,13.58)$. The same journal was also found to be the one most publishing papers from Turkey $(\mathrm{n}=81,17.05 \%)$.

The main source of the publications from all over world was the universities and university hospitals. Table 6 presents top five universities. Pennsylvania State University is the first university of overall $(n=163,1.83 \%)$. The main source of the publications from Turkey was also the universities and university hospitals. Hacettepe University was found to be the first among them $(\mathrm{n}=51,10.7 \%)$.

Table 6. The main source of the publications globally.

\begin{tabular}{lllr}
\hline & Main source name & Number & $\mathbf{\%}$ \\
\hline $\mathbf{1}$ & Pennsylvania State University & 163 & 1.8 \\
$\mathbf{2}$ & University of Athens (Greece) & 153 & 1.7 \\
$\mathbf{3}$ & University of California, Los Angeles & 148 & 1.7 \\
$\mathbf{4}$ & Harvard University & 135 & 1.5 \\
$\mathbf{5}$ & University of Pittsburgh & 131 & 1.5 \\
\hline
\end{tabular}

\section{Discussion}

In this study, we performed a global bibliometric analysis in the field of PCOS and also evaluated the contribution of Turkey to the scientific repertory in this field. Our bibliometric analyses revealed that between 1980 and June 2012, there were 8891 publications written in English originating from Science Citation Index Expanded indexed journals. Among these, 2836 (31.9\%) were from United States of America (USA). Turkey had 475 (5.3\%) publications and ranked fourth. Globally, there were relatively small amount of publications in the field of PCOS between 1980 and 1989. However, we observed an international acceleration with respect to the publication number with early 1990s that reached 1408 (15.8\%) between 1990 and 1999. Remarkable increase in the number of publications from Turkey on the other hand was only after the year of 2000. It is also notable that number of cited papers from Turkey has been increasing meaningfully during the last 10 years. The main source of the publications both globally and from Turkey was the universities and university hospitals.

Evidence-based medical applications is an invaluable approach aiming to evaluate the best available evidence produced by medicine or related medical sciences and to perform the optimal practice by making the best medical decisions. Scientific publication inherently, is one of the most efficient and convenient modalities for disseminating the evidences gained from medicine. Therefore, monitoring the scientific publications is an important way to assess the quality and quantity of the dissemination of medicine based evidences.

With respect to the number of publications, Turkey ranked fourth globally in the field of polycystic ovary syndrome, being the third of several European countries. One reason for this is that Turkey is a Mediterranean country where the incidence of PCOS is relatively high. PCOS incidence in USA is about 3.4-4.7\% however, the incidence is doubled (6.58.7\%) in European countries [9] and more in the Mediterranean region. We believe that advances is reproductive biology may also have an effect in the increased research and publications in the field of PCOS. This is because; management of the metabolic consequences of PCOS is relatively classical when compared to reproductive consequences. Data from European IVF-monitoring (EIM) Consortium for the European Society of Human Reproduction and Embryology (ESHRE); number of the IVF clinics and recorded cycles in register from all over Europe and Turkey are represented Table 78 [10-21]. 
Tables 7. IVF centers in Europe and recorded cycles.

\begin{tabular}{lll}
\hline Years & Clinics reporting to register & Recorded cycles in register \\
\hline $\mathbf{1 9 9 7}$ & 482 & 203893 \\
$\mathbf{1 9 9 8}$ & 521 & 232443 \\
$\mathbf{1 9 9 9}$ & 537 & 258460 \\
$\mathbf{2 0 0 0}$ & 569 & 279267 \\
$\mathbf{2 0 0 1}$ & 579 & 289690 \\
$\mathbf{2 0 0 2}$ & 631 & 324238 \\
$\mathbf{2 0 0 3}$ & 725 & 365103 \\
$\mathbf{2 0 0 4}$ & 785 & 367066 \\
$\mathbf{2 0 0 5}$ & 923 & 418111 \\
$\mathbf{2 0 0 6}$ & 998 & 458759 \\
$\mathbf{2 0 0 7}$ & 1029 & 493184 \\
$\mathbf{2 0 0 8}$ & 1051 & 532260 \\
\hline
\end{tabular}

Tables 8. IVF centers in Turkey and recorded cycles.

\begin{tabular}{llll}
\hline Years & Clinics & Clinics reporting to register & Recorded cycles in register \\
\hline $\mathbf{2 0 0 4}$ & 78 & 4 & 3575 \\
$\mathbf{2 0 0 5}$ & 93 & 61 & 28417 \\
$\mathbf{2 0 0 6}$ & 77 & 77 & 37468 \\
$\mathbf{2 0 0 7}$ & 92 & 92 & 46688 \\
$\mathbf{2 0 0 8}$ & 107 & 107 & 43928 \\
\hline
\end{tabular}

It is interesting to note that there is a positive correlation between the number of infertility clinics and the number of publications in the field of PCOS both in Turkey and globally. We argue that two main reasons can be associated with this positive correlation. Firstly, PCOS patients stand as challenging subjects for infertility treatment and there have been an ongoing research for defining optimal management modalities for these patients. Secondly, as the number of specialized reproductive endocrinologists increased, the interest on pathophysiology and metabolic-reproductive management of PCOS also deepened. This resulted in increased number of publications in the field of PCOS.

Recently in Turkey, reproductive endocrinology is not recognized as an official subspecialty of Obstetrics and Gynecology. We believe that foundation of formal fellowship programs will promote further acceleration for Turkey's performance in the field of PCOS.

The ultimate goal of scientific research and publication in medicine is to make an impact in the clinic, which can be called "clinical impact factor". This aim can be achieved by efficient dissemination of the medicine-based evidences especially via publication. Bibliometric analysis allows us to monitor the scientific activity in a specific topic. Our results indicate that there is a positive trend in both globally and in Turkey for disseminating the findings in the field of polycystic ovary syndrome.

In conclusion, we observed a significant improvement for the global scientific activity in the field of polycystic ovary syndrome during last two decades. Turkey achieved a remarkable contribution to this repertory especially during the last decade. We believe that the emerging of acknowledged fellowship programs with subspecialization, the increasing facilities on PCOS research, and the encouragement originating from the remarkable achievements of the valuable endocrinologists and reproductive endocrinologists from Turkey will help to further increase the Turkey's contribution in PCOS research. 


\section{References}

1. Stein IF. Leventhal NL. Amenorrhea associated with bilateral polycystic ovaries. Am J Obstet Gynecol 1935; 29: 181-91.

2. Homburg R. Polycystic ovary syndrome. Clin Obstet Gynaecol 2008; 2: 261-74.

3. Köşüş N, Köşüş A, Turhan NO. Relationship of ovarian volume with mean platelet volume and lipid profile in patients with polycystic ovary syndrome. Exp Ther Med 2011; 2: 1141-4.

4. Hudecova M, Jan H, Christian B, Poromaa Inger S. Long-term reproductive and metabolic consequences of PCOS. Curr Diabetes Rev 2012; 8: 444-51.

5. Rotterdam ESHRE/ASRM-Sponsored PCOS Consensus Workshop Group. Revised 2003 consensus on diagnostic criteria and long-term health risks related to polycystic ovary syndrome. Fertil Steril 2004; 81: 19-25.

6. Bas KK, Gunay LM, Besim H. Turkey's evaluation in kidney transplantation research. Exp Clin Transplant 2011; 9: 319-22.

7. Andersen J, Belmont J, Cho CT. Journal impact factor in the era of expanding literature. J Microbiol Immunol Infect 2006; 39: 436-43.

8. Akpınar E, Karçaaltincaba M. Analysis of scientific papers in the field of radiology and medical imaging included in Science Citation Index expanded and published by Turkish authors. Diagn Interv Radiol 2010; 16: 175-8.

9. Azziz R, Woods KS, Reyna R, Key TJ, Knochenhauer ES, Yildız BO. The prevalence and features of the polycystic ovary syndrome in an unselected population. J Clin Endocrinol Metab 2004; 89: 2745-9.

10. Nygren KG, Andersen AN. Assisted reproductive technology in Europe, 1997. Results generated from European registers by ESHRE. European IVF-Monitoring Programme (EIM), for the European Society of Human Reproduction and Embryology (ESHRE). Hum Reprod 2001; 16: 384-91.

11. Nygren KG, Andersen AN; European IVF-monitoring programme (EIM). Assisted reproductive technology in Europe, 1998. Results generated from European registers by ESHRE. European Society of Human Reproduction and Embryology. Hum Reprod 2001; 16: 2459-71.

12. Nygren KG, Andersen AN. Assisted reproductive technology in Europe, 1999. Results generated from European registers by ESHRE. Hum Reprod 2002; 17: 3260-74.

13. Nyboe Andersen A, Gianaroli L, Nygren KG; European IVF-monitoring programme; European Society of Human Reproduction and Embryology. Assisted reproductive technology in Europe, 2000. Results generated from European registers by ESHRE. Hum Reprod 2004; 19: 490-503.

14. Andersen AN, Gianaroli L, Felberbaum R, de Mouzon J, Nygren KG; European IVF-monitoring programme (EIM), European Society of Human Reproduction and Embryology (ESHRE). Assisted reproductive technology in Europe, 2001. Results generated from European registers by ESHRE. Hum Reprod 2005; 20: 1158-76.

15. European IVF-monitoring programme (EIM) for the European Society of Human Reproduction and Embryology (ESHRE), Andersen AN, Gianaroli L, Felberbaum R, de Mouzon J, Nygren KG. Assisted reproductive technology in Europe, 2002. Results generated from European registers by ESHRE. Hum Reprod 2006; 21: 1680-97.

16. Andersen AN, Goossens V, Gianaroli L, Felberbaum R, de Mouzon J, Nygren KG. Assisted reproductive technology in Europe, 2003. Results generated from European registers by ESHRE. Hum Reprod 2007; 22: 1513-25.

17. Andersen AN1, Goossens V, Ferraretti AP, Bhattacharya S, Felberbaum R, de Mouzon J, Nygren KG; European IVF-monitoring (EIM) Consortium; European Society of Human Reproduction and Embryology (ESHRE). Assisted reproductive technology in Europe, 2004: results generated from European 
registers by ESHRE. Hum Reprod 2008; 23: 756-71.

18. Nyboe Andersen A1, Goossens V, Bhattacharya S, Ferraretti AP, Kupka MS, de Mouzon J, Nygren KG; European IVF-monitoring (EIM) Consortium, for the European Society of Human Reproduction and Embryology (ESHRE). Assisted reproductive technology and intrauterine inseminations in Europe, 2005: results generated from European registers by ESHRE: ESHRE. The European IVF Monitoring Programme (EIM), for the European Society of Human Reproduction and Embryology (ESHRE). Hum Reprod 2009; 24: 1267-87.

19. de Mouzon J, Goossens V, Bhattacharya S, Castilla JA, Ferraretti AP, Korsak V, Kupka M, Nygren KG, Nyboe Andersen A; European IVF-monitoring (EIM) Consortium, for the European Society of Human Reproduction and Embryology (ESHRE). Assisted reproductive technology in Europe, 2006: Results generated from European registers by ESHRE. Hum Reprod 2010; 25: 1851-62.

20. de Mouzon J, Goossens V, Bhattacharya S, Castilla JA, Ferraretti AP, Korsak V, Kupka M, Nygren KG, Andersen AN; European IVF-Monitoring (EIM); Consortium for the European Society on Human Reproduction and Embryology (ESHRE). Assisted reproductive technology in Europe, 2007: results generated from European registers by ESHRE. Hum Reprod 2012; 27: 954-66.

21. Ferraretti AP, Goossens V, de Mouzon J, Bhattacharya S, Castilla JA, Korsak V, Kupka M, Nygren KG, Nyboe Andersen A; European IVF-monitoring (EIM); Consortium for European Society of Human Reproduction and Embryology (ESHRE). Assisted reproductive technology in Europe, 2008: results generated from European registers by ESHRE. Hum Reprod 2012; 27: 2571-84. 